\title{
Evaluation of technical and economic effect from setup of distributed photovoltaic generation on the Right-of-Way land of the North Caucasus Railway
}

\author{
Ibragim Asanov ${ }^{1}$, Elizaveta Sharaborova ${ }^{2, *}$, and Egor Loktionov ${ }^{2}$ \\ ${ }^{1}$ Moscow Power Engineering Institute (National Research University), Hydropower and renewable energy Department, 111250, \\ Russia, Moscow, Krasnokazarmennaya str. 14, Moscow, Russia \\ ${ }^{2}$ Bauman Moscow State Technical University, Gas Turbine Plants and Nonconventional Power Installations (E3) Department, \\ 105005, Moscow, 2nd Baumanskaya str. 5-1, Moscow, Russia
}

\begin{abstract}
In this work, we consider the concept of using a distributed solar power plant, setup on the right-of-way of the railroad. The proposed solution allows to shave peaks of electricity consumption without additional land alienation, using the existing power grids. The concept includes the setup of solar panels on the alienated land of the railroad. PV can be placed directly on the cross ties using damping elements, on the embankment slopes and on the right-of-way land. This solution allows minimizing the cost of solar panels installation along the railway tracks. The North Caucasus railway was considered to assess the gross, technical and economic potential of the proposed solution. The operational length of the railroad there is $6,472 \mathrm{~km}$. The railway consists of large non-electrified sections, segments powered with $25 \mathrm{kV} \mathrm{AC}$ and $3 \mathrm{kV} \mathrm{DC}$. The railroad is used not only for cargo transport, but also for long-distance and suburban passenger traffic. We have considered different scenarios for right-of-way land use rate and have shown that possible project costs could be reduced by ca. $25 \%$ by double land use only. This does not include shared electric grid infrastructure use that also should benefit considerably, but is hard to be estimated. While the potential nameplate capacity of such power plants within one region is $10 \mathrm{~s}-100 \mathrm{~s}$ of MW.
\end{abstract}

\section{Introduction}

Non-uniform spatial distribution of fuel and energy resources, and existing socio-economic, geographic, and climate factors in Russia lead to substantial costs for their regular supply to regions.

Insufficient modernization of the electric grids required for sustainable economy growth at regional and higher scale, leads to emergence of negative factors affecting all spheres of regions and municipalities development. The restrictive policy for electricity consumption hinders the expansion of industry, affects residential and commercial development, and, as a result, has a negative impact on the economy growth.

According to data provided by Joint-stock Company System Operator of the United Power System and the Russian Ministry of Energy, electricity consumption in Russia in February 2018 increased by 1.7\%, as compared to 2017. At the same time, a record low output to consumed energy ratio is stressed in the South (SFD) and North-Caucasus Federal Districts (NCFD) 1, where the growing energy deficit makes it necessary to buy electricity from neighbor regions. The main areas of electricity consumption are transport, industry, and household. Nowadays, railroads represent the only significantly electrified transport mode, so it is reasonable to consider its energy system transformation 1 .

In this work, we consider the concept of using a distributed solar power plant (SPP) deployed on the right-of-way (ROW) of the the North Caucasus railway (NCR). The solution allows reduction acute peak electricity shortage. It can be made without additional land alienation and new power distribution infrastructure. All this things are possible because the railways are well connected to the power grids. PV power plants can be placed directly on the cross ties using damping elements, on the embankment slopes, and

lisaenergo@yandex.ru 
the rest of ROW land. This solution allows minimizing the cost of solar panels installation along the railway tracks.

\section{The considered area}

The history of global power electricity shows the need of steepwise and planned branch develepment. The implementation of centralised power generation is related to the need for carefully planned investment cycles and to impossibility of sharp technology changes. That means need in electricity infrastructure preparation for new capacities connection 2. Also the equipment obsolescence should be considered. For example, it is known that in Russia about $60 \%$ of thermal power plants (TPP) equipment were put into service more than 30 years ago; $80 \%$ of nuclear power plants (NPP) - more than 20 years ago, and $21 \%$ of hydropower plants - more than 50 years ago 2 .

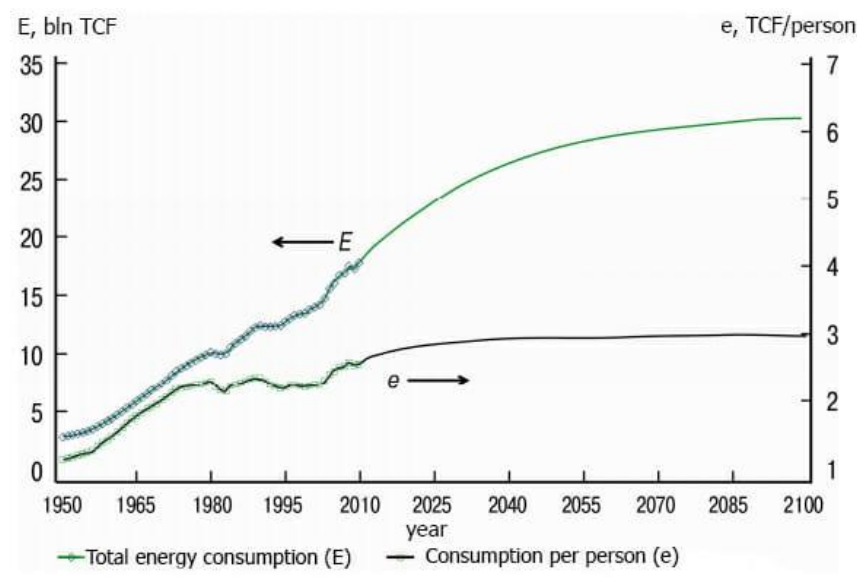

Fig.1. World energy consumption dynamics 4 .

The distributed SPP on the base of NCR can help to unload the energy systems and make it decentralized. Also it is the possibility to enter the reneable sourses into system. The reason why this area can be chosen is its location close to the rapidly developing cities that have sharp energy shortage (Krasnodar, Sochi). Availability of suitable climatic parameters and local PV manufacturing in the Spavropol region also affected on the choice.The operational length of the railroad there is $6,472 \mathrm{~km}$, while the total length of the main railway lines is ca. $6,311 \mathrm{~km}$. The railway consists of large nonelectrified sections, quite large segments powered with
$25 \mathrm{kV}$ AC and short-length parts with $3 \mathrm{kV}$ DC. The road is used not only for cargo transport, but also for long-distance and suburban passenger traffic. We suggest the full cycle energy storage and transportation from SPP to consumer. In addition the secondary use of right-of-way lands is really important for regions with intensive agriculture and resorts, because the cadastral value of land and taxes are high. The railway and adjacent settlements will consume the main part of energy prodused but this way and the surpluses can be send to the wholesale market. Moreover the major surpluses are expected at times with peak electrical load when the electricity cost is maximum. Providing that PV is located in the interrail space, on the slopes and on the right-of-way land in the zones with different insolation, temprature of air and soil, we could calculate the possibility of smoothing the peak load patterns and the increase of total share purchased electricity by the region.

\section{Potential output calculations}

The concept includes the distributed PV generation connected to the traction and public electrical grid. The system feature is easy installation with no need for substructure change (slopes, berms, other structures in the ROW). In calculating the gross, technical and economical potentials, the total area of the railroad ROW land strip was taken. The results were obtained for three scenarios. The optimistic one includes use of whole available area. The realistic one considers partial landuse. And the minimum one suggests use of only one element, in this case, the rail-sleeper grid. Thus, to analyse the generating power orders, it is necessary to calculate the gross potential. The gross potential is the maximum potential that is suitable for solar energy conversion in the area. In other words, the total solar irradiation of the horizontal surface during the year.

$$
W_{G}=E \cdot S,
$$

where $\mathrm{E}$ - the average value of incident solar radiation, $\mathrm{S}$ - considered surface area.

Table 1 shows the average values of the incident solar radiation in regions. To calculate the gross potential, the railway length is also needed (Table 2).

However, the gross potential considers the total energy that is available for conversion and does not consider the efficienty factor. The technical potential can give more reliable result. 
Table 1. The average values of the arrival solar radiation on the light-incident surface, $\mathrm{kWh} / \mathrm{m}^{2}$ month $[5,6]$.

\begin{tabular}{|c|c|c|c|c|c|c|c|c|c|c|c|c|}
\hline Subject/month & 1 & 2 & 3 & 4 & 5 & 6 & 7 & 8 & 9 & 10 & 11 & 12 \\
\hline Adygea & 46,2 & 63,6 & 100,1 & 123,3 & 159,0 & 166,8 & 180,4 & 157,2 & 117,6 & 83,7 & 48,9 & 36,9 \\
\hline Kalmykia & 41,9 & 58,2 & 97,7 & 129,6 & 177,0 & 174,3 & 186,9 & 163,1 & 119,4 & 79,4 & 39,3 & 31,6 \\
\hline Krasnodar Krai & 36,0 & 54,0 & 89,0 & 120,9 & 167,7 & 174,0 & 189,7 & 164,6 & 120,6 & 80,6 & 42,9 & 29,8 \\
\hline Astrakhan Oblast & 40,9 & 60,8 & 104,5 & 132,0 & 177,0 & 180,9 & 189,1 & 164,3 & 122,7 & 80,0 & 40,8 & 31,6 \\
\hline Volgograd Oblast & 29,1 & 38,4 & 97,3 & 123,6 & 182,0 & 177,0 & 188,8 & 164,3 & 107,7 & 68,2 & 33,6 & 19,2 \\
\hline Rostov Oblast & 37,8 & 55,4 & 88,4 & 116,7 & 167,1 & 172,2 & 183,5 & 160,6 & 112,8 & 73,2 & 37,5 & 28,8 \\
\hline Dagestan & 45,9 & 60,8 & 98,3 & 135,6 & 177,3 & 186,6 & 190,7 & 164,6 & 120,0 & 82,2 & 46,8 & 36,9 \\
\hline Ingushetia & 47,7 & 62,4 & 98,6 & 132,3 & 170,5 & 178,8 & 183,2 & 157,5 & 116,7 & 82,8 & 48,9 & 39,4 \\
\hline Kabardino-Balkaria & 50,2 & 66,4 & 102,0 & 120,9 & 151,0 & 150,0 & 158,7 & 142,0 & 111,9 & 87,7 & 54,3 & 44,0 \\
\hline Karachay-Cherkessia & 47,1 & 62,2 & 98,9 & 130,2 & 166,8 & 170,1 & 183,2 & 161,2 & 120,6 & 84,0 & 48,9 & 37,2 \\
\hline North Ossetia - Alania & 50,8 & 66,9 & 103,5 & 129,6 & 164,0 & 167,4 & 173,0 & 149,7 & 113,4 & 84,9 & 54,0 & 43,1 \\
\hline Chechnya & 49,3 & 65,8 & 102,9 & 133,8 & 171,7 & 177,9 & 183,8 & 156,6 & 117,3 & 84,6 & 51,6 & 42,2 \\
\hline Stavropol Krai & 41,5 & 59,4 & 95,2 & 124,2 & 169,0 & 173,4 & 188,2 & 164,6 & 120,0 & 82,2 & 44,4 & 32,6 \\
\hline
\end{tabular}

Table 2. The total PV square placed on the railways according to the scenarios, $\mathrm{m}^{2}$ [7].

\begin{tabular}{|c|c|c|c|}
\hline Subject/operation square & Minimal & Realistic & Optimistic \\
\hline Adygea & 160100 & 320200 & 480300 \\
\hline Kalmykia & 164800 & 329600 & 494400 \\
\hline Krasnodar Krai & 2139900 & 4279800 & 6419700 \\
\hline Astrakhan Oblast & 629600 & 1259200 & 1888800 \\
\hline Volgograd Oblast & 1617200 & 3234400 & 4851600 \\
\hline Rostov Oblast & 1912700 & 3825400 & 1526100 \\
\hline Dagestan & 508700 & 1017400 & 116400 \\
\hline Ingushetia & 38800 & 77600 & 151800 \\
\hline Kabardino-Balkaria & 133300 & 266600 & 431400 \\
\hline Karachay-Cherkessia & 50600 & 101200 & 912300 \\
\hline North Ossetia - Alania & 143800 & 287600 & 2765400 \\
\hline Chechnya & 304100 & 608200 & 100 \\
\hline Stavropol Krai & 921800 & 1843600 & \\
\hline
\end{tabular}

The technical potential is the total energy that is converted and used at present technology development stage. To get the technical potential, data of PV manufacturers were used. According to those, the efficiency of commercially available silicon panels is about $21-23 \% 8$. Also the total system includes inverters with efficiency about $98 \% 9$. Since energy is trasfered to traction substations without intermediate accumulation, energy storage was not considered:

$$
W_{T}=E \cdot S \cdot \eta \cdot\left(1-\chi\left(T_{i}-T\right)\right),
$$

where $\mathrm{T}_{\mathrm{i}}$ - the average monthly PV temperature, $\mathrm{K}$; $\mathrm{E}-$ solar irradiation, $\mathrm{kW} / \mathrm{m}^{2} /$ month; $\mathrm{S}$ - considered area, $\mathrm{m}^{2}$; $\mathrm{T}$ - monthly average ambient temperature, $\mathrm{K} ; \eta-\mathrm{PV}$ conversion efficiency; $\chi$ - the temperature coefficient.

The gross and technical potentials for SFD and NCFD subjects are listed in table 3. 
Table 3. Gross and technical potentials of solar energy generation, $\mathrm{MWh} / \mathrm{year}$

\begin{tabular}{|c|c|c|c|c|c|c|}
\hline \multirow[t]{3}{*}{ Subject } & \multicolumn{3}{|c|}{ Gross potential } & \multicolumn{3}{|c|}{ Technical potential } \\
\hline & \multicolumn{6}{|c|}{ Scenarios } \\
\hline & Minimal & Real & Optimal & Minimal & Real & Optimal \\
\hline Adygea & 205520 & 411040 & 616561 & 40939 & 81879 & 122818 \\
\hline Kalmykia & 213976 & 427952 & 641928 & 42624 & 85248 & 127872 \\
\hline Krasnodar Krai & 2717245 & 5434490 & 8151735 & 541275 & 1082550 & 1623825 \\
\hline Astrakhan Oblast & 833968 & 1667936 & 2501904 & 166126 & 332252 & 498379 \\
\hline Volgograd Oblast & 1987862 & 3975724 & 5963586 & 395982 & 791964 & 1187946 \\
\hline Rostov Oblast & 2360271 & 4720543 & 7080815 & 470166 & 940332 & 1410498 \\
\hline Dagestan & 684557 & 1369115 & 2053672 & 136363 & 272727 & 409091 \\
\hline Ingushetia & 51169 & 102338 & 153508 & 10192 & 20385 & 30578 \\
\hline Kabardino-Balkaria & 165172 & 330344 & 495516 & 32902 & 65804 & 98706 \\
\hline Karachay-Cherkessia & 66306 & 132612 & 198918 & 13208 & 26416 & 39624 \\
\hline North Ossetia - Alania & 186983 & 373966 & 560949 & 37247 & 74494 & 111741 \\
\hline Chechnya & 406733 & 813467 & 1220201 & 81021 & 162042 & 243064 \\
\hline Stavropol Krai & 1193454 & 2386908 & 3580363 & 237736 & 475472 & 713208 \\
\hline
\end{tabular}

For the further effectiveness comparison during the power plant life cycle, efficiency assessment is required for suggested and usual solutions. Electrity production cost during the life cycle, from the stage of design to the object liquidation. This parameter is known as levelized cost of electricity production. It includes all investment costs and incomes that are possible. Usually the results are obtained in $\$ / \mathrm{kWh}$ for $20-40$ years long life cycle 10 . The levelized cost of electricity (LCOE) is calculated using formula:

$$
L C O E=\frac{\frac{I+M+F}{(1+r)^{t}}}{\frac{E}{(1+r)^{t}}},
$$

where I - annual investment expenses, \$; M - annual operation and maintenance expenses, $\$ ; \mathrm{F}$ - fuel expenses, \$; E - total electricity output per year, $\mathrm{kWh}$; - refinancing rate; $\mathrm{t}$ - system life cycle, years.

Table 4 shows the share of land value in investment expenses. The results can be very significant and take more than a half of the whole cost. We have estimated possible benefits at land double-use for the suggested solution - see table 5 .

Table 4. Capital costs, RUR/kWh [11-13]

\begin{tabular}{|c|c|c|c|c|c|c|}
\hline $\begin{array}{c}\text { SPP } \\
\text { name }\end{array}$ & $\begin{array}{c}\text { Total } \\
\text { investment, } \\
\text { RUR }\end{array}$ & $\begin{array}{c}\text { Annual } \\
\text { electricity } \\
\text { output, MWh }\end{array}$ & $\begin{array}{c}\text { ROW, } \\
\text { hectare }\end{array}$ & $\begin{array}{c}\text { Nominal land } \\
\text { cost, RUR }\end{array}$ & \multicolumn{2}{|c|}{ Capital cost, RUR/kWh } \\
\cline { 5 - 7 } & $570 \mathrm{M}$ & 5800 & 40 & $6.452 \mathrm{M}$ & 3,2 & 3,2 \\
\hline Kosh-Agach SPP & $600 \mathrm{M}$ & 6500 & 69 & $344.903 \mathrm{M}$ & 3,07 & 1,3 \\
\hline Abakan SPP & $3000 \mathrm{M}$ & 32000 & 105 & $407.620 \mathrm{M}$ & 3,125 & 2,7 \\
\hline $\begin{array}{c}\text { Orsk SPP named } \\
\text { after A.A. } \\
\text { Vlaznev }\end{array}$ & & & & & \\
\hline
\end{tabular}


Table 5. Estimated investment cost benefits at ROW land double use.

\begin{tabular}{|c|c|c|c|c|}
\hline Subject & $\begin{array}{c}\text { Installed power in } \\
\text { terms of range, } \mathrm{kW}\end{array}$ & $\begin{array}{c}\text { Investments with } \\
\text { the value of ROW, } \\
\text { million rubles }\end{array}$ & $\begin{array}{c}\text { Proposed solution } \\
\text { investments } \\
\text { million rubles }\end{array}$ & $\begin{array}{c}\text { Expected benefits, } \\
\text { million rubles }\end{array}$ \\
\hline Adygea & 32020 & 199,8 & 153,7 & 46,1 \\
\hline Kalmykia & 32960 & 205,7 & 158,2 & 67,5 \\
\hline Krasnodar Krai & 427980 & 2670,6 & 2054,3 & 18,3 \\
\hline Astrakhan Oblast & 125920 & 785,7 & 604,4 & 465,8 \\
\hline Volgograd Oblast & 323440 & 2018,3 & 1552,5 & 550,9 \\
\hline Rostov Oblast & 382540 & 2387,1 & 1836,2 & 146,5 \\
\hline Dagestan & 101740 & 634,9 & 488,4 & 11,2 \\
\hline Ingushetia & 7760 & 48,4 & 37,3 & 38,4 \\
\hline Kabardino-Balkaria & 26660 & 166,4 & 128 & 14,6 \\
\hline Karachay-Cherkessia & 10120 & 63,1 & 48,6 & 41,4 \\
\hline North Ossetia - Alania & 28760 & 179,5 & 138,1 & 87,6 \\
\hline Chechnya & 60820 & 379,5 & 291,9 & 265,5 \\
\hline Stavropol Krai & 184360 & 1150,4 & 884,9 & \\
\hline
\end{tabular}

\section{Conclutions}

Consumed to produced electricity ratio analysis has revealed territories with acute energy shortage. All these regions have to buy electricity from the neighbors. In Russia, many of such regions are situated within Southern and North Caucauss federal districts. Quite long section of $\mathrm{DC}$ and $\mathrm{AC}$ electrified railroads can be found there. We suggest the solution based on the distributed solar power plant that could help to use modern power sources at reduced investment load. Because of comparatively high average solar irradiation, the LCOE shows that investment burden can be reduced by $15-30 \%$. Such reduction means that extra generated powers can be started to remove energy shortage in the regions.

This work was supported by the Russian Foundation for Basic Research and Russian Railways (joint grant 17-20-05181).

\section{References}

1. RIA Rating The rating of regions on power sufficiency level in 2017 URL: http://vid1.rian.ru/ig/ratings/energodeficit012018.pdf (SO UPS, JSC, 2019)

2. I. M. Asanov, E. Y. Loktionov, Possible benefits from $P V$ modules integration in railroad linear structures (REF, 2018)

3. B. B. Kobets, I. O. Volkov, Innovative development of power industry on the basis of the concept of Smart Grid (IATs Energy, Moscow, 2010)

4. V.Ya. Ushakov, Modern problems of power industry (Tomsk Polytechnic University, 2014)

5. Climatological data for the territory of the Russian Federation (RETScreen, NASA SSE)
6. Scientific-applied reference book on climate of the USSR, 13 (Gidrometeoizdat, Leningrad, 1990)

7. Russian Federation, Federal State Statistics Service URL:

http://www.gks.ru/wps/wcm/connect/rosstat_main/rossta $\mathrm{t} / \mathrm{ru} /(22.03 .2019)$

8. D. Gielen, R. Kempener, M. Taylor, F. Boshell, A. Seleem, Letting in the Light: How Solar Photovoltaics Will Revolutionise the Electricity System (IRENA, 2016)

9. Fraunhofer Institute for Solar Energy Systems: Photovoltaics Report, ISE (ISE, Freiburg, 2016)

10. Russian National Committee (RNC CIGRE) URL: http://www.cigre.ru/research_commitets/ik_rus/c5_rus $/ \mathrm{m}$ aterials/docs (22.03.2019)

11. About the approval of the scheme and the program of Altai Republic's power indystry development for $2017 \quad 2021 \quad$ URL: http://altairepublic.ru/document/download/6743 (22.03.2019)

12. Energybase.ru Abakan PV URL: https://energybase.ru/power-plant/abakan-solar-powerplant (22.03.2019)

13. The Orsk PV named after A.A. Vlaznev, PJSC TPlus URL: https://www.tplusgroup.ru/org/orenburg/organization/ors kaja-sehs-im-aa-vlazneva/ (22.03.2019) 